\title{
Correction to: The Impact of a Gamified E-Learning Environment in Students Attitude: A Case Study
}

\author{
Marcos M. Tenório (D), Francisco Reinaldo (D), Vitor Gonçalves (D), \\ Eliana C. Ishikawa (D), Lourival A. Góis (D), \\ and Guataçara dos Santos Jr(D)
}

\section{Correction to: \\ Chapter "The Impact of a Gamified E-Learning Environment in Students Attitude: A Case Study" in: M. E. Auer and D. Centea (Eds.): Visions and Concepts for Education 4.0, AISC 1314, https://doi.org/10.1007/978-3-030-67209-6_43}

In the original version of the book, the following belated correction has been incorporated: In Chapter 43, the author's name has been changed from "Vitor Goçalves" to "Vitor Gonçalves" 